\title{
NEMZETKÖZI KONFERENCIA A FOGYATÉKOS SZEMÉLYEK INKLUZÍV OKTATÁSÁRÓL BUDAPESTEN
}

\author{
VÁRKONYI ZOLTÁN \\ a Szövetség az Életen Át Tartó Tanulásért \\ projekt koordinátora \\ conference@alll.hu
}

A fogyatékossággal élő személyek jogairól szóló ENSZ-egyezmény kimondja, hogy az inkluzív és színvonalas oktatáshoz való jog egyetemesen megillet minden gyermeket, fiatalt és felnőttet, köztük a fogyatékos személyeket is. Az iskolák többségében a bizonytalanság és a szükséges tudás hiánya azonban megnehezíti e cél elérését. „A befogadáshoz vezetö utak” (Pathways to Inclusion) elnevezésü, hároméves nemzetközi Comenius projekt a gyakorlati munkát kívánja segíteni. A projekt zárórendezvényét 2012. szeptember 13-14-én tartotta a Fogyatékos Személyeknek Szolgáltató Szervezetek Európai Szövetsége (EASPD), melynek hazai partnere a Szövetség az Életen Át Tartó Tanulásért.

$\mathrm{Az}$ „Inkluzív oktatás és tanulás: Kihivások és lehetöségek” című budapesti konferencia föként az együttnevelés és élethosszig tartó tanulás jelenlegi uniós helyzetének bemutatására, illetve a fennálló kihívásokra adható lehetséges válaszok felvázolására vállalkozott, érintve a tanulás valamennyi formáját az iskola előtti neveléstől egészen a felnőttkori tanulásig. A rendezvényre több mint 40 országból közel 250 résztvevő érkezett, s közel 60 előadót hallgathatott meg. Az aktív mühelymunkák során pedig külföldi és hazai jó gyakorlatok megosztására nyílt lehetöség. Csoportokban beszélgettek a résztvevők a „mindenki iskolája” megteremtéséhez kapcsolódó fö kihívások lehetséges megoldásairól is.

Megállapítást nyert, hogy az inkluzív oktatás fó célja az eredményes tanulást hatékonyan támogató tanulási környezet létrehozása, amelyben minden érintett részt vesz, és ahol minden tanuló számára biztosított az esélyegyenlőség és az egyenlő bánásmód.

A konferencia előtti napon kísérörendezvényként öt budapesti és két tatabányai oktatási intézménybe, köztük egy-egy szakiskolába szervezett látogatást a Szövetség az Életen Át Tartó Tanulásért. A meglátogatott budapesti helyszínek: Pannónia Általános Iskola (XIII. ker.), Neumann János Számítástechnikai Szakközépiskola (XIV. ker.), Gyermekek Háza (II. ker.), Pitypang Óvoda (XIII. ker.) és Eötvös Általános Iskola (XIII. ker.). Tatabányán a Sárberki Általános Iskola és Mikes Kelemen Felnőtt és Ifjúsági Gimnázium, Szakközépiskola és Szakiskola fogadta az érdeklődőket. A budapesti intézmények egy része a Prizma Egységes Gyógypedagógiai 
Módszertani Intézmény szakmai támogatásával müködik: értelmi sérült és/vagy sajátos nevelési igényü tanulókkal foglalkoznak, példamutató módon és eredményekkel. A meglátogatott tatabányai intézményeket pedig az Éltes Mátyás Egységes Gyógypedagógiai Módszertani Intézmény támogatja. Az EGYMI-ben dolgozó gyógypedagógusok, szakemberek innovációkkal segítik a befogadó pedagógusok munkáját és igény esetén más intézményeket is.

Az intézménylátogatásokon 42 fő vett részt. A nemzetközi csapat visszajelzéseiből kiderül, melyek a bemutatott intézmények erősségei: jó a dolgozók hozzáállása a tanulókhoz, magas az oktatás színvonala és a pedagógusok felkészültsége. A kooperativ (társas) tanulási modell is pozitív visszhangra talált. Többen hangsúlyozták, hogy a kiválasztott magyar fogadóintézmények európai mércével mérve is kiemelkedő eredményeket értek el az inkluzív oktatás területén.

A konferencia eredményeit összegzö jelentés, valamint az együttnevelésröl szóló Budapesti Nyilatkozat és Cselekvési Terv hamarosan elérhető lesz a www. pathwaystoinclusion.eu honlapon.

További információk: Szövetség az Életen Át Tartó Tanulásért, info@alll.hu 